\title{
Chemical Analysis of Coffee Berry Volatiles That Elicit an Antennal Response From the Coffee Berry Borer Hypothenemus hampei
}

\author{
Elías Neptalí Cruz Roblero and Edi A. Malo* \\ El Colegio de la Frontera Sur (ECOSUR). Grupo de Ecología de artrópodos y manejo de plagas. Km. 2.5 Carretera Antiguo \\ Aeropuerto, Apartado Postal 36, Tapachula, 30700, Chiapas, México. emr@ecosur.mx
}

Received December 6, 2012; Accepted June 17, 2013.

\begin{abstract}
One of the major obstacles to coffee production worldwide is the damage caused by the coffee berry borer Hypothenemus hampei (Ferrari; Coleoptera: Curculionidae). When searching for host fruits, females are attracted to the volatiles the fruits release. In this study, the volatiles released by the ripe and dry fruits of Coffea arabica and $C$. canephora were analyzed by gas chromatography-electroantennography (GC-EAD) and identified by gas chromatography-mass spectrometry (GC-MS). The areas of the response peaks were analyzed using canonical discriminant analysis. The results of the statistical analysis demonstrated the presence of 4 distinct groups of volatiles released from ripe and dry C. arabica and C. canephora. A few of the most influential compounds in the canonical discriminate analysis also elicited antennal activity (GC-EAD) in the flying female coffee berry borers, specifically 2-heptanone, 2-heptanol, 3-ethyl-4-methylpentanol, phenyl ethyl alcohol, methyl salicylate, and $\alpha$-copaene. These compounds will be tested in the field to explore the development of a new chemical that is attractive to the borers and can be used in the management of the coffee berry borer $H$. hampei.

Keywords: Coffe volatiles, Antennal response, EAG, Hypothenemus hampei, Coleoptera.
\end{abstract}

\section{Introduction}

Plants from the Coffea (Rubiaceae) genus are important crops in many tropical countries. This genus is composed of 103 species (Davis et al., 2006), but only two of the species are commercially traded: $C$. arabica $\mathrm{L}$. and $C$. canephora Pierre ex A. Froehner (colloquially referred to as "robusta"). Coffea arabica grows best at high altitudes, whereas $C$. canephora is grown at lower altitudes $[1,2]$. Both species of Coffea can be grown in either total sunlight or in various levels of shade [3, 4]. The production of Coffea has increased over the past few decades through the use of high yielding varieties, fertilizers and high density planting [5]. However, coffee production is severely affected by numerous pests and diseases. One of the major obstacles to coffee production worldwide is the damage caused by the coffee berry borer Hypothenemus hampei (Ferrari; Coleoptera: Curculionidae), which is a small beetle endemic to Central Africa [6, 7]. The males cannot fly, and they generally spend their entire lives inside the coffee fruit. Once they reach sexual maturity, they mate with their sibling females within the fruit before the females leave their native fruits [7]. After adult eclosion, the female coffee berry borers abandon their native fruits and disperse to colonize and oviposit in new fruits [8]. Most of the life cycle of this organism is spent inside coffee berries, which makes this insect difficult to control through either chemical or non-chemical strategies.
Resumen. Uno de los mayores problemas que afectan la producción de café en el mundo por el daño que ocasionan es la broca del café, Hypothenemus hampei (Ferrari; Coleoptera: Curculionidae). Una hembra es orientada por los compuestos volátiles liberados por la hospedera durante el proceso de búsqueda. Los compuestos volátiles liberados por frutos maduros y secos de Coffea arabica y C. canephora fueron analizados por cromatografía de gases-electroantenografia (CG-EAG) e identificados por cromatografía de gases-espectrometría de masas (CG-EM) en este trabajo. El área de cada compuesto fue analizado usando un análisis discriminante canónico. Los resultados del análisis estadístico muestran 4 grupos: maduro y seco de $C$. arabica y maduro y seco de C. canephora. Algunos compuestos que influyen el análisis discriminante canónico, también mostraron actividad antenal (CGEAG) a hembras voladoras de la broca del café, por ejemplo, 2-heptanona, 2-heptanol, 3-etil-4-metilpentanol, 2-phenyl etanol, salicilato de metilo, y $\alpha$-copaeno. Sin embargo, estos compuestos deberán de ser evaluados en campo para explorar la posibilidad de desarrollar una mezcla atrayente para el manejo de la broca del café, $H$. hampei.

Palabras clave: Volátiles de café, Respuesta antenal, EAG, Hypothenemus hampei, Coleoptera.

The main method that is currently used to control the coffee berry borer in tropical America is the application of synthetic insecticides. However, endosulfan and chlorpyrifos, which are the two insecticides most commonly used against $H$. hampei, are highly toxic and are a threat to the environment, to the farmers who use them, and to the communities living adjacent to the treated coffee plantations [5]. In addition, the use of insecticides increases the likelihood that the coffee beans will contain residual pesticides that can affect human health and the environment. Furthermore, the continuous use of insecticides may induce resistance to them in the coffee berry borer and thus reduce their effectiveness $[9,10]$. In locating host plants [11], insects use a combination of visual and chemical cues, plant volatiles being particularly significant for the latter [12]. There is evidence that $H$. hampei uses both visual $[11,13,14]$ and olfactory stimuli $[14,15,16]$ to locate host plants. Consequently, the volatiles emitted from the coffee berries play an essential role [12] in the attraction of H. hampei to the coffee plant. However, the volatiles that are responsible for this attraction have not yet been identified; most likely because the small size of the antennae of $H$. hampei makes it difficult to obtain electrophysiological recordings. A study of the blend of volatiles released from Coffea arabica fruits at different maturation stages was reported recently [17]; an olfactometer bioassay was used to identify the volatile semiochemicals that attract $H$. hampei: methylcyclohexane, ethylbenzene, nonane 
and 3-ethyl-4-methylpentanol [17]. In this study, the volatile compounds that are released by Coffea arabica and C. canephora fruits were identified and used in statistical multivariate analysis and chromatography-electroantennography (GCEAD) to identify the most important compounds released by the coffee fruits. These results will contribute to the development of new attractants that, when combined with traps, could provide innovative and sustainable management of the coffee berry borer.

\section{Results and Discussion}

The presences of secondary metabolites in fruit volatiles from both species of coffee were detected. The statistical analysis of the compounds present in the coffee fruit volatiles showed a significant difference between the groups $(\mathrm{F}=2.26$; $\mathrm{df}=3$, 48; $\mathrm{P}<0.01)$. The results of the Mahalanobis test show the distance between the 4 groups ripe $C$. arabica fruit, dry $C$. arabica fruit, ripe $C$. canephora fruit, and dry $C$. canephora fruit. This analysis revealed that the greatest distance (37.64) was between the volatiles from the ripe $C$. arabica fruit and the volatiles from the dry $C$. canephora fruit. These results suggest that the centroid of the ripe $C$. arabica fruit is more distant than the centroid of the C. canephora dry fruit (Table 1). In contrast, the distance between the ripe and the dry $C$. canephora fruits is the shortest (Table 1). This work identified 24 secondary metabolites in the volatiles collected from the ripe C. arabica fruit (Table 2), of which mesitylene, $\alpha$-cedrene, and $\alpha$-copaene were the most important (Fig. 1). Similarly, 23 compounds were identified in the volatiles collected from the dry C. arabica fruit (Table 2), and the most important were methyl salicylate, benzyl alcohol, 3-ethyl-4-methylpentanol, linalool, 2-heptanone, 2-heptanol, and phenylethyl alcohol (Fig. 1). In addition, 26 compounds were identified in the volatiles from the ripe C. canephora fruit (Table 3), of which limonene and $\alpha$-copaene were the most important (Fig. 1). Regarding the volatiles from the dry C. canephora fruit, 28 compounds were identified (Table 3), and 2-heptanol, limonene and phenyl ethyl alcohol were the most important (Fig. 1).

In a study of the blend of volatiles released from Coffea arabica fruits at different maturation stages, the authors found more volatiles with biological activity in ripened fruits than in green fruits [17], including compounds such as 3-ethyl-4methylpentanol, 2-heptanol and methyl salicylate. The results

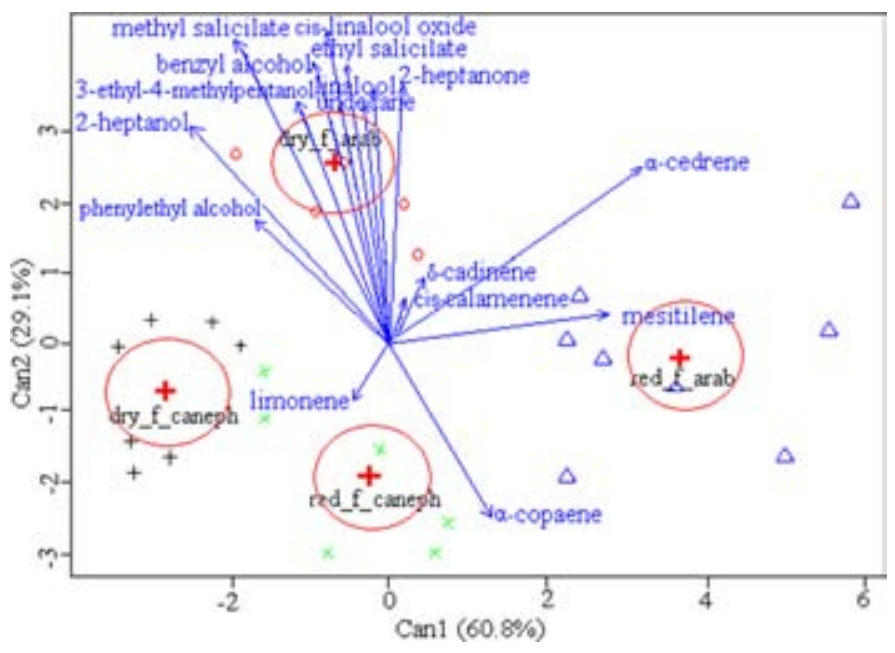

Fig. 1. Representation of groups of ripe and dry fruits of $C$. arabica and $C$. canephora using a discriminate analysis (90\% yields).

of the identification of compounds in coffee berry volatiles from the present study concur with those previously reported [18]. For example, compounds such as hexanal, 1-hexanol, 2heptanone, 2-heptanol, isobutyl butyrate, linalool, and methyl salicylate were found in volatiles from C. arabica and Coffea canephora berries in this and previous works. However, parts of the results of this identification differ from those reported by Ortiz et al. (2004) [19]. That study found that the most abundant compound in coffee berry volatiles was ethanol. In contrast, our study found that the most abundant volatile compounds were linalool and methyl salicilate in the ripe and dry C. arabica fruits, while limonene and methyl salicilate were the most abundant volatile compounds in the ripe and dry $C$. canephora fruit. A few of the metabolites found in our study, such as 2-heptanone, heptanol, and 3-methyl-4- ethylpentanol, have been previously identified in the volatiles of ripe and overripe berries of C. arabica [18]. Similarly, metabolites such as methyl salicylate, $\alpha$-copaene and $\delta$-cadinene have been identified in volatiles released by the healthy ripe berries of $C$. canephora [20].

Regarding the response of the flying female coffee berry borers to the fruit volatiles, the results obtained from the canonical discriminant analysis and the GC-EAD assays were similar. For example, the volatile compounds from the ripe $C$. arabica fruit that influenced the flying female coffee berry borers in the discriminant analysis were $\alpha$-cedrene and $\alpha$-copaene.

Table 1. Results of Mahalanobis test applied to coffee fruit stages of maturity.

\begin{tabular}{lcccc}
\hline \multicolumn{1}{c}{ Coffee fruits } & \multicolumn{4}{c}{ Distance between groups } \\
\hline & Ripe fruits & Ripe fruits & Dry fruits & Dry fruits \\
\hline Ripe fruits (arabica) & 0 & $($ canephora $)$ & $($ arabica $)$ & $($ canephora $)$ \\
Ripe fruits (canephora) & 19.64 & 19.64 & 27.83 & 16.74 \\
Dry fruits (arabica) & 27.83 & 0 & 0 & 13.21 \\
Dry fruits (canephora) & 37.64 & 16.74 & 11.63 & 0 \\
\hline
\end{tabular}


Table 2. Volatiles from C. arabica fruits of collected by dynamic aeration.

\begin{tabular}{|c|c|c|}
\hline & Ripe fruits & Dry fruits \\
\hline Compounds & $\% \pm$ E.E & $\% \pm$ E.E \\
\hline Ethyl benzene ${ }^{1}$ & $0.3 \pm 0.32$ & $0.00 \pm 0.00$ \\
\hline 2-Heptanone ${ }^{1,2,3, *}$ & $1.09 \pm 0.93$ & $0.26 \pm 0.14$ \\
\hline 2-Heptanol $1^{1,2,3, *}$ & $0.51 \pm 0.62$ & $1.73 \pm 1.19$ \\
\hline 5-Methyl-1-heptene ${ }^{1}$ & $0.00 \pm 0.00$ & $0.61 \pm 0.85$ \\
\hline Cumene $^{1}$ & $3.43 \pm 5.52$ & $0.00 \pm 0.00$ \\
\hline Acid hexanoic ${ }^{1}$ & $0.00 \pm 0.00$ & $0.20 \pm 0.22$ \\
\hline 6-methyl-5-hepten-2-one ${ }^{1,2}$ & $1.39 \pm 2.39$ & $0.79 \pm 0.90$ \\
\hline Mesitilene $e^{1,2^{*}}$ & $9.82 \pm 10.73$ & $0.00 \pm 0.00$ \\
\hline$(\alpha)$-Phelandrene $e^{1,2}$ & $0.02 \pm 0.05$ & $0.00 \pm 0.00$ \\
\hline 3-ethyl-4-methylpentanol $1^{1,2,3, *}$ & $5.32 \pm 8.83$ & $10.64 \pm 14.8$ \\
\hline Limonene $^{1,2,3, *}$ & $2.34 \pm 2.21$ & $1.11 \pm 1.42$ \\
\hline$(\beta)$-Phelandrene $e^{1,2}$ & $2.85 \pm 3.85$ & $0.00 \pm 0.00$ \\
\hline Benzyl Alcohol ${ }^{1,2,3, *}$ & $0.00 \pm 0.00$ & $7.73 \pm 9.43$ \\
\hline 2-indanol $1^{1,2,3}$ & $4.12 \pm 4.39$ & $0.00 \pm 0.00$ \\
\hline Unknown & $0.00 \pm 0.00$ & $1.69 \pm 1.63$ \\
\hline (cis)-Linalool oxide ${ }^{1,2,3,{ }^{*}}$ & $0.00 \pm 0.00$ & $2.09 \pm 1.99$ \\
\hline$(p-)-C i m e n e n e^{1,2}$ & $8.15 \pm 10.31$ & $0.00 \pm 0.00$ \\
\hline (trans)-Linalool oxide ${ }^{1,2,3}$ & $0.00 \pm 0.00$ & $2.09 \pm 1.95$ \\
\hline Undecane $^{1,2,3,{ }^{*}}$ & $1.11 \pm 1.12$ & $1.29 \pm 1.34$ \\
\hline Linalool $^{1,2,3, *}$ & $10.69 \pm 8.63$ & $4.91 \pm 4.29$ \\
\hline Unknown & $5.99 \pm 6.08$ & $0.00 \pm 0.00$ \\
\hline$(\alpha)$-Fenchocamphorone $^{1}$ & $0.00 \pm 0.00$ & $3.54 \pm 2.92$ \\
\hline Unknown & $4.44 \pm 5.06$ & $0.00 \pm 0.00$ \\
\hline phenyletyl alcohol ${ }^{1,2,3, *}$ & $0.00 \pm 0.00$ & $1.37 \pm 2.57$ \\
\hline (p)1,3,8-Menthatriene $e^{1,2}$ & $0.00 \pm 0.00$ & $0.45 \pm 0.63$ \\
\hline$(\mathrm{m})$-Cimene ${ }^{1}$ & $1.16 \pm 1.09$ & $0.00 \pm 0.00$ \\
\hline Linalool oxide $<$ trans $>$ (piranoide) ${ }^{1}$ & $0.00 \pm 0.00$ & $1.02 \pm 1.15$ \\
\hline Pirazina 2-metoxi-3-(2-ethylpropyl) 1,2 & $4.1 \pm 4.30$ & $0.00 \pm 0.00$ \\
\hline Unknown & $2.72 \pm 2.28$ & $0.00 \pm 0.00$ \\
\hline Methyl Salicilate ${ }^{1,2,3, *}$ & $0.00 \pm 0.00$ & $49.05 \pm 40.4$ \\
\hline Ethyl Salicilate ${ }^{1,2, *}$ & $0.00 \pm 0.00$ & $3.63 \pm 3.87$ \\
\hline p-tert-butylbenzyl alcohol ${ }^{1}$ & $2.01 \pm 1.45$ & $0.00 \pm 0.00$ \\
\hline$(\alpha)$-Copaene $e^{1,2,3,{ }^{*}}$ & $8.29 \pm 5.18$ & $0.55 \pm 0.39$ \\
\hline$(\alpha)$-Cedrene $e^{1,2,3^{*}}$ & $7.46 \pm 4.49$ & $0.00 \pm 0.00$ \\
\hline$(\beta)$-Cedrene ${ }^{1,2}$ & $0.00 \pm 0.00$ & $0.65 \pm 0.96$ \\
\hline$(\delta)$-Cadinene $e^{1,2^{*}}$ & $5.39 \pm 3.38$ & $0.92 \pm 1.45$ \\
\hline (Cis)-Calamenene ${ }^{1,2^{*}}$ & $4.84 \pm 3.62$ & $0.29 \pm 0.36$ \\
\hline
\end{tabular}

${ }^{1}$ The identification was made comparing the mass spectra with the NIST-98 data base. ${ }^{2}$ Compounds identified by comparing the Kovats retention index and mass spectra with those reported by [26]. ${ }^{3}$ Compounds identified using the mass spectra compared with the synthetic compounds. *Volatiles used in multivariate analysis. $\mathrm{N}=8$.

The GC-EAD analysis of the response of the flying female coffee berry borers to the volatile compounds from the ripe $C$. arabica fruit indicated antennal activity to $\alpha$-copaene (Table 4 ). Of the volatiles from the dry C. arabica fruit, the compounds that showed the most influence on the flying female coffee berry borers, when subject to canonical discriminant analysis, were methyl salicylate, 3-ethyl-4-methylpentanol, linalool, 2heptanone, 2-heptanol, and phenyl ethyl alcohol. The GC-EAD 
Table 3. Volatiles from C. canephora fruits, collected by dynamic aeration.

\begin{tabular}{|c|c|c|}
\hline & Ripe fruits & Dry fruits \\
\hline Compounds & $\% \pm$ E.E & $\% \pm$ E.E \\
\hline 2-heptanone ${ }^{1,2,3, *}$ & $0.4 \pm 0.58$ & $0.36 \pm 0.76$ \\
\hline 2-Heptanol ${ }^{1,2,3, *}$ & $0.00 \pm 0.00$ & $4.43 \pm 8.40$ \\
\hline$\alpha$-pinene $e^{1,2,3}$ & $1.47 \pm 1.37$ & $0.06 \pm 0.19$ \\
\hline$(\beta)$-pinene $e^{1,2}$ & $1.07 \pm 0.94$ & $0.00 \pm 0.00$ \\
\hline 1-Nonen-4-ol ${ }^{1}$ & $0.00 \pm 0.00$ & $0.19 \pm 0.27$ \\
\hline Mesitilene ${ }^{1,2, *}$ & $3.86 \pm 5.56$ & $0.34 \pm 0.88$ \\
\hline 3-Ethyl-4-Methylpentanol, ${ }^{1,2,3,}{ }^{*}$ & $0.00 \pm 0.00$ & $1.51 \pm 2.19$ \\
\hline Limonene $^{1,2,3, *}$ & $14.73 \pm 13.03$ & $0.94 \pm 1.46$ \\
\hline Benzyl Alcohol ${ }^{1,2,3, *}$ & $0.00 \pm 0.00$ & $2.4 \pm 2.48$ \\
\hline Unknown & $2.81 \pm 3.69$ & $0.00 \pm 0.00$ \\
\hline 7-octen-ol,2.6-dimethyl ${ }^{1}$ & $0.00 \pm 0.00$ & $0.61 \pm 0.80$ \\
\hline (cis)-Linalool oxide ${ }^{1,2,3, *}$ & $0.00 \pm 0.00$ & $0.67 \pm 0.79$ \\
\hline (trans)-Linalool oxide ${ }^{1,2,3}$ & $0.00 \pm 0.00$ & $0.63 \pm 1.24$ \\
\hline (p)-1,3,8-mentatrieno ${ }^{1,2,3}$ & $1.46 \pm 0.82$ & $0.00 \pm 0.00$ \\
\hline Undecane $^{1,2,3,{ }^{*}}$ & $2.16 \pm 1.05$ & $0.86 \pm 1.50$ \\
\hline Linalool $^{1,2,3,{ }^{*}}$ & $10.89 \pm 16.8$ & $3.28 \pm 3.81$ \\
\hline Unknown & $0.00 \pm 0.00$ & $1.78 \pm 1.46$ \\
\hline Fenylethyl alcohol ${ }^{1,2,3, *}$ & $0.00 \pm 0.00$ & $3.93 \pm 6.17$ \\
\hline Unknown & $0.92 \pm 0.62$ & $0.00 \pm 0.00$ \\
\hline Mentone $e^{1,2,3}$ & $0.94 \pm 1.60$ & $0.54 \pm 0.69$ \\
\hline Limonene oxide ${ }^{1,2}$ & $0.00 \pm 0.00$ & $0.45 \pm 0.77$ \\
\hline Pirazina 2-metoxi-3-(2-ethylpropyl) $)^{1,2}$ & $1.26 \pm 1.88$ & $0.00 \pm 0.00$ \\
\hline Unknown & $0.00 \pm 0.00$ & $1.05 \pm 1.26$ \\
\hline Mentol $^{1,2,3}$ & $1.46 \pm 1.18$ & $0.00 \pm 0.00$ \\
\hline 4-Terpinol $1^{1,2,3}$ & $1.48 \pm 1.47$ & $0.00 \pm 0.00$ \\
\hline Methyl salicilate ${ }^{1,2,3, *}$ & $8.61 \pm 13.3$ & $55.84 \pm 40.8$ \\
\hline Ethyl salicilate ${ }^{1,2,3, *}$ & $0.00 \pm 0.00$ & $2.69 \pm 3.37$ \\
\hline Olelyl alcohol ${ }^{1,2}$ & $4.69 \pm 4.69$ & $0.00 \pm 0.00$ \\
\hline Unknown & $0.00 \pm 0.00$ & $5.09 \pm 6.43$ \\
\hline Acid butanoico, butylester ${ }^{1}$ & $0.00 \pm 0.00$ & $3.12 \pm 6.06$ \\
\hline$\alpha$-Copaene $e^{1,2,3, *}$ & $7.35 \pm 3.27$ & $2.89 \pm 2.47$ \\
\hline Thujopsene ${ }^{1,2}$ & $4.42 \pm 3.34$ & $0.00 \pm 0.00$ \\
\hline$(\alpha)$-Bergamotene $\mathrm{e}^{1,2,3}$ & $2.17 \pm 1.93$ & $0.00 \pm 0.00$ \\
\hline 2,6,di-tert, butilbenzoquinona ${ }^{1}$ & $4.14 \pm 3.94$ & $0.00 \pm 0.00$ \\
\hline Alo-aromandrene $e^{1,2}$ & $4.82 \pm 5.68$ & $0.00 \pm 0.00$ \\
\hline Curcumene ${ }^{1,2}$ & $4.09 \pm 3.54$ & $2.35 \pm 1.88$ \\
\hline$(\alpha)$-Chamigrene ${ }^{1,2}$ & $5.32 \pm 4.42$ & $0.00 \pm 0.00$ \\
\hline$(\alpha)$-Cedrene $e^{1,2,3^{*}}$ & $5.26 \pm 1.49$ & $0.23 \pm 0.10$ \\
\hline Cadinene ${ }^{1,2^{*}}$ & $5.54 \pm 2.77$ & $1.44 \pm 1.18$ \\
\hline Calamenene (cis) $)^{1,2^{*}}$ & $3.95 \pm 2.59$ & $1.92 \pm 1.71$ \\
\hline Unknown & $0.00 \pm 0.00$ & $0.67 \pm 0.97$ \\
\hline
\end{tabular}

${ }^{1}$ The identification was made comparing the mass spectra with the NIST-98 data base. ${ }^{2}$ Compounds identified by comparing the Kovats retention index and mass spectra with those reported by [26]. ${ }^{3}$ Compounds identified using the mass spectra compared with the synthetic compounds. *Volatiles used to multivariate analysis. $\mathrm{N}=8$. 
Table 4. Mean GC-EAG response $(\mathrm{mV} \pm \mathrm{S}$. E.) elicited by flight female H. hampei to ripe and dry fruit volatiles from C. arabica.

\begin{tabular}{|c|c|c|c|c|}
\hline \multicolumn{5}{|c|}{ Accuracy in $\%(n=10)$} \\
\hline Compounds & Ripe fruits & Response in $\mathrm{mV}$ & Dry fruits & Response in $\mathrm{mV}$ \\
\hline 2-Indanol & 70 & $0.77 \pm 0.18$ & & \\
\hline Monoterpene & 50 & $0.86 \pm 0.17$ & & \\
\hline$\alpha$-Copaene & 50 & $0.817 \pm 0.17$ & & \\
\hline 6-Methyl-5-hepten-2-ona & & & 50 & $0.54 \pm 0.29$ \\
\hline 3-Ethyl-4-methyilpentanol & & & 70 & $2.85 \pm 1.93$ \\
\hline (Cis)-Linalool oxide & & & 50 & $1.11 \pm 0.56$ \\
\hline Methyl Salicilate & & & 80 & $0.88 \pm 0.47$ \\
\hline
\end{tabular}

Table 5. Mean GC-EAG response ( $\mathrm{mV} \pm \mathrm{S}$. E.) elicited by flight female H. hampei to ripe and dry fruit volatiles from C. canephora.

\begin{tabular}{|c|c|c|c|c|}
\hline \multirow[b]{2}{*}{ Compounds } & \multicolumn{4}{|c|}{ Accuracy in $\%(n=10)$} \\
\hline & Red fruits & Response in $\mathrm{mV}$ & Dry fruits & Response in $\mathrm{mV}$ \\
\hline Trimethyl-bencene & 60 & $0.58 \pm 0.14$ & & \\
\hline Phenilethyl alcohol & & & 70 & $0.57 \pm 0.19$ \\
\hline (Cis)-Limonene oxide & & & 50 & $0.41 \pm 0.09$ \\
\hline Ethyl Salicilate & & & 50 & $0.45 \pm 0.11$ \\
\hline$\alpha$-Copaene & 50 & $0.81 \pm 0.25$ & & \\
\hline
\end{tabular}

assay of the response of the flying female coffee berry borers to the volatiles from the dry $C$. arabica fruits indicated antennal activity to 2-heptanone, 2-heptanol, 3-ethyl-4-methylpentanol, cis-linalool oxide, methyl salicylate and ethyl salicylate (Table 4). The most important compounds from the canonical discriminant analysis of the volatiles from the dry $C$. canephora fruit were limonene and $\alpha$-copaene. The GC-EAD analysis of the response of the flying female coffee berry borers to the volatiles from the ripe C. canephora fruit showed antennal activity to 3-ethyl-4-methylpentanol, methyl salicylate and $\alpha$ copaene (Table 5). The most important compounds identified in the volatiles from the dry $C$. canephora fruit were 2-heptanol, limonene, and phenyl ethyl alcohol. The GC-EAD analysis of the same volatiles showed peaks that were identified as phenyl ethyl alcohol, methyl salicylate and ethyl salicylate (Table 5). Of the compounds identified from the coffee berry volatiles in this study, 2-heptanol, ethyl benzene, 3-ethyl-4-methylpentanol, and methyl salicylate had been previously identified [17]. However, as in this study, only 3-ethyl-4-methylpentanol elicited an antennal response from the coffee berry borers [17]. This research includes the identification of other volatile compounds that elicit an antennal response from the female coffee berry borers, the chemical analysis of coffee berry fruits, and the canonical discriminate analysis of the identified compounds.
This study found that the female berry coffee borers were able to discriminate between different volatiles emitted from the coffee berries. Statistical analysis showed that the odor profiles differ between different volatiles. One advantage of using multivariate analysis to examine the fruit volatiles is that it focuses on the differences in the volatile patterns rather than on single compounds [21]. Thus, multivariate analysis is quite similar to the olfactory processing in the insects that base their behavioral decisions on the differences in the volatile profiles between plants [21].

In conclusion, the volatiles identified in ripe and dry $C$. arabica and $C$. canephora, the canonical discriminant analysis and the GC-EAD assays suggest a mixture of berry compounds composed of 2-heptanone, 2-heptanol, 3-ethyl4-methylpentanol, phenyl ethyl alcohol, methyl salicylate, and $\alpha$-copaene, that will be tested in the field to confirm the activity of the compounds against to the coffee berry borer H. hampei.

\section{Experimental}

Two coffee fruits, Coffee arabica L. and Coffee canephora Pierre ex Froehner, were used in this study. Ripe and dry fruits 
from both varieties were collected because the ripe stage is preferred by females for oviposition in the fruits and because both stages produce compounds that are known to be active to the coffee berry borer [17]. The fruits were collected in Finca Alianza, which is located in Cacahoatán, Chiapas, México 727 meters above sea level $\left(15^{\circ} 02^{\prime} \mathrm{N}, 92^{\circ} 10^{\prime} \mathrm{W}\right)$. The fruits were collected (1 kg, free from insect infestation) using gloves and entomological scissors; the peduncle was left attached to the berry. The fruits were collected from 09:00 to 11:00 am, placed in plastic bags and transported immediately to ECOSUR for collection and chemical analysis of the volatiles.

The flying female coffee berry borers that were used in the GC-EAD analysis were obtained from infested fruits collected in the field. The fruits were transported to the laboratory and placed inside a wooden cage $(30 \times 45 \mathrm{~cm})$ held at a controlled temperature $\left(22 \pm 2{ }^{\circ} \mathrm{C}\right)$ and a controlled relative humidity $(70$ $\pm 5 \%$ ). The wooden cage was exposed to $75 \mathrm{~W}$ light the following day, and the flying females started to leave the fruits and were caught in glass vials.

The previously described technique [22] used in this study for the collection of the volatiles utilized a cylindrical glass aeration chamber $(40 \mathrm{~cm}$ long $\times 21 \mathrm{~cm}$ i.d. $)$. The volatiles were collected using ripe and dry coffee berries. A charcoal-filtered airstream (1 1 per min) was passed through the glass aeration chamber for $72 \mathrm{~h}$. The fruit volatiles were collected on Super Q (50-80 mesh; Water Associates, Milford, MA, USA) packed between plugs of silanized glass wool in a Pasteur pipette. The fruit volatiles were eluted from the Super Q with $400 \mu \mathrm{l}$ of dichloromethane (HPLC grade), placed in glass vials and stored at $-20{ }^{\circ} \mathrm{C}$ until analysis. A total of 32 samples were analyzed (8 at each stage of maturity for each species of fruit).

GC-EAD studies were carried out to identify the components in the coffee fruit volatiles that caused an antennal reaction using a previously described system [23]. These studies were performed with a gas chromatograph (GC) (Varian 3600 ) coupled to an electroantennogram (EAG). The GC was equipped with a capillary column (DB5 MS, $25 \mathrm{~m}$ by $0.25 \mathrm{~mm}$ i.d.), a flame ionization detector (FID), and a split/splitless injector, which was operated in the splitless mode. Helium was used as the carrier gas at a flow rate of $2.0 \mathrm{ml} / \mathrm{min}$. The oven temperature was first set at $50{ }^{\circ} \mathrm{C}$ for $2 \mathrm{~min}$, then increased at a rate of $8{ }^{\circ} \mathrm{C} / \mathrm{min}$ to $280{ }^{\circ} \mathrm{C}$, and held for $10 \mathrm{~min}$ at $280{ }^{\circ} \mathrm{C}$. At the end of the capillary column, a splitter (VSOS, Scientific Instruments Services, Ringoes, NJ, USA) distributed the effluent from the column to the FID and to a transfer line toward the prepared EAG [24]. Both connections were composed of deactivated fused silica of the same length and diameter such that the column effluent was split in a ratio of 1 (EAG) to 1 (FID). The EAD preparations were made using one antenna carefully cut from a flying female and inserted into the reference glass capillary electrode, which was filled with a physiological saline solution [25]. The antenna club was connected to the tip of the recording glass capillary electrode. The signals generated by the antenna and the FID were passed through a high-impedance amplifier (NL 1200, Syntech, Hilversum, the Netherlands) and displayed on a monitor using the Syntech version 2.6 software
(2003) for the processing of the GC-EAD signals. A current of humidified pure air $(0.7 \mathrm{l} / \mathrm{min})$ was constantly directed at the antenna through a $10 \mathrm{~mm}$ diameter glass tube using a stimulus flow controller (CS-05, Syntech). One replicate result was obtained for each female antenna, and 10 females were used to analyze each stage of maturity for each species of coffee.

The GC-MS analyses were performed using a GC (Varian CP-800) equipped with a DB5-MS capillary column (30 $\mathrm{m}$ by $0.25 \mathrm{~mm}$ and a coat thickness of $0.25 \mu \mathrm{m}$ ) and a Varian Saturn 2200 ion trap mass detector. The oven temperature was initially set at $50^{\circ} \mathrm{C}$ for $2 \mathrm{~min}$, then increased at a rate of 15 ${ }^{\circ} \mathrm{C} / \mathrm{min}$ to $280{ }^{\circ} \mathrm{C}$, and held at this temperature for $10 \mathrm{~min}$. The injector temperature was $250{ }^{\circ} \mathrm{C}$. The injector was operated in the splitless mode. Helium was used as the carrier gas at a flow rate of $1.0 \mathrm{ml} \mathrm{min}^{-1}$. Ionization was determined by electron impact at $70 \mathrm{eV}$. The tentative identification of the compounds was based on a comparison of the mass spectra with the NIST MS Library. The identification of some of the compounds was confirmed through a comparison of the mass spectra and the retention times of the compounds with those of standards, which were purchased from Sigma-Aldrich (Toluca, Mexico) and, according to the supplier, had a purity of 97-99 $\%$. Compounds for which a standard was not available were identified by comparing the Kovats retention index and mass spectra with those previously reported [26]. The abundance of a particular compound was quantified using its peak area. The peak area of a particular compound was then converted into a percentage of the sum of the peak areas of all of the targeted GC peaks to determine the relative abundance of the compound.

The results were analyzed using the statistical Minitab package, version 15.1 [27]. This study identified 16 compounds that were present in the four groups of volatiles released by the ripe and dry fruits of $C$. arabica and C. canephora. A multivariate analysis was performed using the peak areas of the compounds. This analysis was performed considering that canonical discriminant analysis is a technique that permits the differentiation between two or more groups and takes into account the performance measure of the individuals of each group [28]. The ripe and dry fruits of both species of coffee constituted the groups. The canonical discriminant analyses indicate whether there is a significant difference between the groups, determine which groups are different, and enable the identification of the variables that contribute most to this difference. A canonical discriminant analysis, which involved the use of the Mahalanobis test, was applied to compare the distances between the groups.

\section{Acknowledgments}

The authors thank Leopoldo Cruz López and Antonio Santiesteban (ECOSUR) for their help during the identification process. In addition, the authors acknowledge the technical support provided by Enrique Pascacio (ECOSUR) in the collection of the flying female coffee berry borers. The authors would also like to thank CONACyT (Consejo Nacional de 
Ciencia y Tecnología) grant 62316 to Leopoldo Cruz López and FORDECYT (grant 116306) for providing the financial support for this project.

\section{References}

1. Wintgens, J. N. (Ed). Coffee: Growing, processing, sustainable production. Wiley-VCH, Weinheim, 2004.

2. Vega, F. E. American Scientist 2008, 96, 138-145.

3. Muschler, R. G. in: Coffee: growing, processing, sustainable production, Wintgens, J. N. (ed.), Wiley-VCH Verlag, Weinheim, 2004, 391-418.

4. Perfecto, I.; Armbrecht, I.; Philpott, S. M.; Soto-Pinto, L.; Dietsch, T. V. in: Stability of tropical rainforest margins: linking ecological, economic and social constraints of land use and conservation, Tscharntke, T.; Leuschner, C.; Zeller, M.; Guhardja, E.; Bidin, A. (Eds), Springer Verlag, 2007, 227-263.

5. Baker, P.S.; Jackson, J. A. F.; Murphy, S. T. Natural enemies, natural allies. Project completion report of the integrated management of coffee berry borer project, CFC/ICO/02 (1998-2002). The commodities press. CABI commodities, Egham UK and Cenicafé, Chinchiná, Colombia. 2002.

6. Le Pelley, R. H. Pests of coffee. Longmans, Green and Co., Ltd., 1968.

7. Waterhouse, D. F.; Norris, K. R. Biological control. Pacific Prospects- Supplement 1. Australian Centre for International Agricultural Research, Canberra, Australia, 1989.

8. Baker, P. S.; Barrera, J. F.; Rivas, A. J. Appl. Ecol. 1992, 29, 656662.

9. Brun, L.O.; Marcillaud, C.; Gaudichon, V.; Suckling, D. M. J. Econ. Entomol. 1989, 82, 1311-1316.

10. Góngora, C. E.; Posada, F. J.; Bustillo, A. E. Detección molecular de un gen de resistencia al insecticida endosulfan en una población de broca Hypothenemus hampei(Ferrari) (Coleoptera: Scolytidae) en Colombia. Congreso de la Sociedad Colombiana de Entomología, August 8-10, 2001, Pereira, Colombia.
11. Bernays, E. A.; Chapman, R. F. Host-plant Selection by Phytophagous Insects. Contemporary Topics in Entomology 2. Chapman and Hall, 1994.

12. Bruce, J. A.; Wadhams, L. J.; Woodcock, C. M. Trends Plant Sci. 2005, 10, 269-274.

13. Morallo-Rejesus, B.; Baldos, E. Philippine Entomol. 1980, 4, $303-$ 316.

14. Mathieu, F.; Gaudichon, V.; Brun, L. O.; Frérot, B. Physiol. Entomol. 2001, 26: 189-193.

15. Giordanengo, P.; Brun, L. O.; Frerot, B. J. Chem. Ecol. 1993, 19, 763-769.

16. Mendoza-Mora, J. R. Reposta da broca-do-café, Hypothenemus hampei, a estimulos visuais e semioquimicos. Tese Magister Scientiae, Universidade Federal de Vicosa, Brazil, 1991.

17. Mendesil, E.; Bruce J. A.; Woodcock C. M.; Caulfield J. C.; Seyoum E.; Pickeett, J. A. J. Chem. Ecol. 2009, 35, 944-950.

18. Mathieu, F.; Malosse, C.; Frerot, B. J. Agric. Food Chem. 1998, 46, 1106-1110.

19. Ortiz, A.; Ortiz, A.; Vega, F. A.; Posada, F. J. Agric. Food Chem. 2004, 52, 5914-5918.

20. Román-Ruíz, A. K.; Malo, E. A.; Huerta, G.; Castillo, A.; Barrera, J. F.; Rojas, J. C. Arthropod-Plant Interactions, 2012, DOI 10.1007/s11829-012-9197-0

21. van Dam, N. M,; Poppy, G. M. Plant Biology, 2008, 10, 29-37.

22. Blight, M. M., in: Chromatography and Isolation of Insect Hormones and Pheromones, McCaffery, A. R.; Wilson, I. D. (eds.), Plenum Press, 1990, 281-288.

23. Arn, H.; Stadler, E.; Rauscher, S. Z. Naturforsch. 1975, 30C, $722-$ 725.

24. Malo, E. A.; Cruz-López, L.; Toledo, J.; Del Mazo, A.; Virgen, A.; Rojas, J. C. Fla. Entomol. 2005, 88, 364-370.

25. Malo, E. A.; Castrejón-Gómez, V. R.; Cruz-López, L.; Rojas, J. C. Ann. Entomol. Soc. Am. 2004, 97, 1273-1284.

26. Adams, R. P. Identification of essential oil compounds by gas chromatography/mass spectrometry, $4^{\text {th }}$ Ed. Allured Publishing; Carol Stream, IL, USA: 2007.

27. Minitab package, version 15.1 (Minitab Inc.), 2007.

28. Hair, J. F. Jr.; Anderson, R. E.; Tatham, R. L.; Black, W. C. Análisis multivariante. 5ta Ed. Prentice Hall Iberia, 1999. 